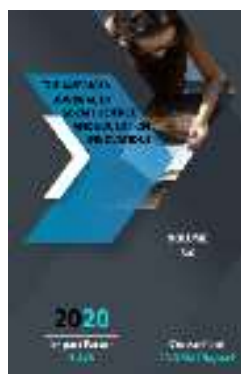

\title{
East And West: Integration And Cooperation In The Process Of Globalization
}

\author{
Ochilova Nigora Ruzimuratovna \\ Associate Professor, Social Sciences", Karshi Engineering And Economics Institute, Karshi, \\ Uzbekistan
}

\begin{abstract}
Journal Website: http://usajournalshub.c om/index,php/tajssei

Copyright: Original content from this work may be used under the terms of the creative commons attributes 4.0 licence.
\end{abstract}

\section{ABSTRACT}

The urgency of this problem is that the number of concepts devoted to the spiritual and cultural crisis of modern civilization is growing rapidly. The process of globalization, which is a characteristic feature of modern civilization, has also intensified the conflict between East and West. So far, the Western world can set prices for these types of products, spread information technology around the world, and make them an important part of modern manufacturing. As a result, the gap between developed and developing countries is widening. Any attempt by developing countries to "catch up" will end in temporary success.

\section{KEYWORDS}

Civilization, integration, world economy, modern technologies, information, strategic and geopolitical integration, strengthening cooperation, foreign investment, capital and products, free movement of labor

\section{INTRODUCTION}

The urgency of this problem is that the number of concepts devoted to the spiritual and cultural crisis of modern civilization is sharp. growing. The process of globalization, which is a characteristic feature of modern civilization, has also intensified the conflict between East and West. So far, the Western world can set prices for these types of products, spread information technology around the world, and make them an important part of modern manufacturing. As a result, the gap between developed and developing countries is widening. Any attempt by developing countries to "catch up" will end in temporary success. 
The information features of modern civilization led to the formation of a new phenomenon called globalization in the late twentieth - early twenty-first century. In other words, on the eve of the new century, the connection between countries and regions has strengthened, the connection between events and processes, problems and situations in various fields around the world has increased, the use of science and technology in social life has expanded.

The impact of modern technology is universal, and information technology is closely linked to human destiny. Figuratively speaking, today means that various fields around the world have proliferated, and the use of science and technology in public life has expanded.

The impact of modern technology is universal, and information technology is closely linked to human destiny. Figuratively speaking, today's means of communication have "reduced" the Earth to the size of a village. The world has become more rounded and coordinated with iteconomic development further strengthens this unity.

\section{MATERIALS AND METHODS}

"In particular, strengthening integration and cooperation between countries and peoples, creating conditions for foreign investment, capital and goods, free movement of labor, creating many new jobs, the speed of modern communication and information technology, scientific advances." Globalization, the harmonization of different values on a universal basis, the acquisition of a new quality of communication between civilizations, increasing the opportunities for mutual assistance in the event of environmental disasters - all this is associated with globalization. "[1.5-111-112]

The process of globalization and changes in the field of culture have brought modern civilization first from bipolar to one pole and then from one pole to more. In both bipolar worlds, the concepts of "East" and "West" themselves have risen to the level of an ideological dimension, shifting from a geographical concept to a political and ideological category. Exactly the ideological dimension is the main criterion for a bipolar world, and other countries of the world have united around this two poles on the basis of this dimension - around the USSR and the USA. That is why Japan, located in the Far East, has become an integral part of the Western world. [2.c-14]. The crisis of the Soviet empire led to the emergence of a unipolar world.

The unipolar world ruled until the late 1990 . During this period, the United States sought to change the world in accordance with its value system. The economic, financial, diplomatic, and military mechanisms created by the United States serve the dream of Americanizing the entire world. On the eve of the new century, the United States did not even listen to the opinion of international organizations and international experts. But 10 years was enough for the U.S.'s global reputation to decline. A few minutes ago, U.S. Secretary of State K.V. "The United Statesthey have no permanent enemies, "Rice said." Surprisingly, the United States didn't even have permanent friends. American militarism, attempts to Americanize different nations, chauvinism, and nihilism have led many nations to turn away from the United States. Even the term "evil empire" appeared in the world media.

The unipolar world ruled until the late 1990s. During this period, the United States sought to change the world in accordance with its value system. The economic, financial, diplomatic, and military mechanisms created by the United States serve the dream of Americanizing the entire world. On the eve of the new century, the United States did not even listen to the opinion of international organizations and international experts. But 10 years was enough for the U.S.'s global reputation to decline. A few minutes ago, 
U.S. Secretary of State K.V. "The United States has no permanent enemies," Rice said. Surprisingly, the United States didn't even have permanent friends. American militarism, attempts to Americanize different nations, chauvinism, and nihilism have led many states to turn away from the United States. Even the term "evil empire" has appeared in the world media. [3.C-7]. In the last 30 years of the twentieth century, the following changes have taken place in Eastern and Western civilization:

1. The economic structure of the East and West economies has changed radically, the market economy has stabilized.

2. New economic needs have raised the development of science and technology to a whole new level.

3. As a result of the growth of the value and social significance of information, the information society is stabilized.

4. The powerful development of science and technology, in turn, is newtrend - the process of globalization.

5. There is a process of combining traditional and modern culture.

6. Multipolarity has begun to take shape in the global geopolitical arena.

The formation of the information society, the rapprochement of social relations between nations and peoples, the integration of the world economy should have ended at first glance with the establishment of the "golden age".

\section{RESULT AND DISCUSSION}

Surprisingly, the number of works devoted to the contradictions and problems of modern civilization is increasing. For example, Yale University professor P. Kennedy noted that "trends that emerged just three generations ago are still exacerbating social relations and even threatening human life" [4.c-86]. Rector of the International Academy of Systemic Studies in Vienna E.J. According to Laszlo, "the problems of modern human society are not accidental and incomplete, but modern civilization is in the final stages of decline." [5.c-85].

In particular, criticism of Western civilization is growing. According to A. Zinoviev, a Russian scholar who lived in the West for many years, "The transformation of the West into a post-industrial society is tantamount to its transformation into a social organism, obese due to its high degree of arbitrariness.

In conclusion, like other forms of propaganda, the evolution of spiritual propaganda involves a process that has lasted for more than 5,000 years. It is possible the spiritual propaganda of the ancient world in the conditional period, the spiritual propaganda of the Middle Ages, the spiritual propaganda of the Renaissance, the spiritual propaganda of the new centurypropaganda, studied as the spiritual propaganda of the modern period. [6.s-220].

Over time, this has a very negative effect on his ability to be self-sufficient "[7.s-144]. Academician B. Rauschenbach, who studied the features of the Western world in detail, writes: "They only eat and drink, they only consume - life is like a plant and this life is like a mold: there is something above and there is nothing below." [8.c-424].

The number of concepts dedicated to the spiritual and cultural crisis of modern civilization is growing rapidly. Interestingly, during the twentieth century, the crisis of human civilization was recognized in three main concepts: [9.s-424]. In the last 10-15 years of the twentieth century and the beginning of the 21st century, many articles have been published in support of this idea. [10.c-424].

\section{CONCLUSION}

The changes that have taken place in Eastern and Western civilizations and their social consequences have certainly not gone 
unnoticed. Innovations radically change not only the economic, social, political and spiritual-ideological image of human society, but also the way of life, way of thinking, value system and social activity.

\section{REFERENCES}

1. Karimov I. High spirituality - is an invincible force, 2008. - 111-112-p.

2. Choriev S. Ideological image of the modern world. - T .: Ijod olami, 2003. - 14bet 3 .

3. Kennedy $P$. Introduction to the 21st Century, Moscow: Ves Mir, 1997, p. 386.

4. Laszlo E. Bifurcation period // Road.- 1995. - № 7. - P. 85.

5. R.R. Rustamov. S. B. Elboyeva. Evolution of the system of spiritual propaganda // SOI: 1.1 / TAS DOI: 10.15863 / TAS International Scientific Journal Theoretical and Applied Scientific p-ISSN: 2308-4944 (print) e-ISSN: 2409-0085 (online) Year: 2020 Published: 2020 volume: 90 .Published: 14.10.

6. A.A.Zinoviev West. The phenomenon of Westernism), Moscow: Nauka, 1995, p.144.

7. Raushenbax B.V. Drugs.- $M$ : Ves Mir, 1997.- P. 424.

8. Bell D. Future postindustrial society: the experience of social forecasting.- $M$.: Academia, 2004; Fromm E. Escape from Freedom. - Moscow: Acad. Project, 2007; Spengler $O$. The Decline of Europe. Gestalt and truth. Essays on the morphology of world history.- M .: Eksmo, 2006.

9. Buchanan P. Death of the West. - M .: AST, 2007; Toynbee A. Civilization before the Court of History.-M .: AIRIS PRESS, 2006; Fukuyama $F$. The end of history and the last man.- M. AST, 2007; Hayek F. The Road to Slavery.-

10. Moscow: Liberal Fund. Mission: New Publishing, 2005; Huntington S. Clash of Civilizations.- M: AST, 2006.

11. www.ecsocman.edu.ru/images/pubs/200 4/04/03/0000153589/012iONOW.pdf
12. www.ecsocman.edu.ru/images/pubs/200 4/04/03/0000153589/012iONOW.pdf

13. www.nsu.ru/filf/rpha/papers/civ/wilkinsn. htm - 114k

14. http://www.pravoslavie.ru/jurnal/03111012 2623. 